NASA/TM-2001-211317

Enhancement of Pool Boiling Heat Transfer and Control of Bubble Motion in Microgravity Using Electric Fields (BCOEL)

Cila Herman and Estelle Iacona

Johns Hopkins University, Baltimore, Maryland

Tom Acquaviva, Bill Coho, Nechelle Grant, Henry Nahra, and Al Taylor

Glenn Research Center, Cleveland, Ohio

Ed Julian, Dale Robinson, and Dave VanZandt

ZIN Technologies, Inc., Brook Park, Ohio 
Since its founding, NASA has been dedicated to the advancement of aeronautics and space science. The NASA Scientific and Technical Information (STI) Program Office plays a key part in helping NASA maintain this important role.

The NASA STI Program Office is operated by Langley Research Center, the Lead Center for NASA's scientific and technical information. The NASA STI Program Office provides access to the NASA STI Database, the largest collection of aeronautical and space science STI in the world. The Program Office is also NASA's institutional mechanism for disseminating the results of its research and development activities. These results are published by NASA in the NASA STI Report Series, which includes the following report types:

- $\quad$ TECHNICAL PUBLICATION. Reports of completed research or a major significant phase of research that present the results of NASA programs and include extensive data or theoretical analysis. Includes compilations of significant scientific and technical data and information deemed to be of continuing reference value. NASA's counterpart of peerreviewed formal professional papers but has less stringent limitations on manuscript length and extent of graphic presentations.

- TECHNICAL MEMORANDUM. Scientific and technical findings that are preliminary or of specialized interest, e.g., quick release reports, working papers, and bibliographies that contain minimal annotation. Does not contain extensive analysis.

- CONTRACTOR REPORT. Scientific and technical findings by NASA-sponsored contractors and grantees.
- CONFERENCE PUBLICATION. Collected papers from scientific and technical conferences, symposia, seminars, or other meetings sponsored or cosponsored by NASA.

- SPECIAL PUBLICATION. Scientific, technical, or historical information from NASA programs, projects, and missions, often concerned with subjects having substantial public interest.

- TECHNICAL TRANSLATION. Englishlanguage translations of foreign scientific and technical material pertinent to NASA's mission.

Specialized services that complement the STI Program Office's diverse offerings include creating custom thesauri, building customized data bases, organizing and publishing research results ... even providing videos.

For more information about the NASA STI Program Office, see the following:

- Access the NASA STI Program Home Page at http://www.sti.nasa.gov

- E-mail your question via the Internet to help@sti.nasa.gov

- Fax your question to the NASA Access Help Desk at 301-621-0134

- Telephone the NASA Access Help Desk at 301-621-0390

- Write to:

NASA Access Help Desk

NASA Center for AeroSpace Information 7121 Standard Drive

Hanover, MD 21076 
NASA/TM-2001-211317

AIAA-2001-5115

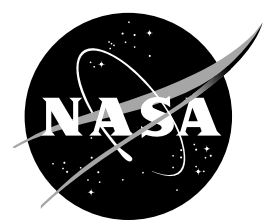

\section{Enhancement of Pool Boiling Heat Transfer and Control of Bubble Motion in Microgravity Using Electric Fields (BCOEL)}

Cila Herman and Estelle Iacona

Johns Hopkins University, Baltimore, Maryland

Tom Acquaviva, Bill Coho, Nechelle Grant, Henry Nahra, and Al Taylor Glenn Research Center, Cleveland, Ohio

Ed Julian, Dale Robinson, and Dave VanZandt ZIN Technologies, Inc., Brook Park, Ohio

Prepared for the International Space Station Utilization-2001 sponsored by the American Institute of Aeronautics and Astronautics Cape Canaveral, Florida, October 15-18, 2001

National Aeronautics and Space Administration

Glenn Research Center 


\section{Acknowledgments}

The research reported in this paper was supported by NASA Grant NAG3-1815. The experiments in the KC-135 aircraft were carried out by Cila Herman, Gorkem Suner, Steven Marra and Ed Scheinerman. The support by the KC -135 crew and by NASA Glenn Research Center was invaluable for the successful completion of the experiments described in the paper.

Trade names or manufacturers' names are used in this report for identification only. This usage does not constitute an official endorsement, either expressed or implied, by the National Aeronautics and Space Administration.

Available from

NASA Center for Aerospace Information 7121 Standard Drive

Hanover, MD 21076
National Technical Information Service 5285 Port Royal Road Springfield, VA 22100 


\title{
ENHANCEMENT OF POOL BOILING HEAT TRANSFER AND CONTROL OF BUBBLE MOTION IN MICROGRAVITY USING ELECTRIC FIELDS (BCOEL)
}

\author{
Cila Herman and Estelle Iacona \\ Department of Mechanical Engineering \\ The Johns Hopkins University, Baltimore, MD
}

Tom Acquaviva, Bill Coho, Nechelle Grant, Henry Nahra, and Al Taylor
National Aeronautics and Space Administration
Glenn Research Center, Cleveland, OH

Ed Julian, Dale Robinson and Dave VanZandt

ZIN Technologies, Cleveland, $\mathrm{OH}$

\begin{abstract}
The BCOEL project focuses on improving pool boiling heat transfer and bubble control in microgravity by exposing the fluid to electric fields. The electric fields induce a body force that can replace gravity in the low gravity environment, and enhance bubble removal from the heated surface. A better understanding of microgravity effects on boiling with and without electric fields is critical to the proper design of the phase-change-heat-removal equipment for use in space-based applications. The microgravity experiments will focus on the visualization of bubble formation and shape during boiling. Heat fluxes on the boiling surface will be measured, and, together with the measured driving temperature differences, used to plot boiling curves for different electric field magnitudes. Bubble formation and boiling processes were found to be extremely sensitive to g-jitter. The duration of the experimental run is critical in order to achieve steady state in microgravity experiments. The International Space Station provides conditions suitable for such experiments. The experimental apparatus to be used in the study is described in the paper. The apparatus will be tested in the $\mathrm{KC}-135$ first, and microgravity experiments will be conducted on board of the International Space Station using the Microgravity Science Glovebox as the experimental platform.
\end{abstract}

\section{INTRODUCTION}

In boiling high heat fluxes are possible driven by relatively small temperature differences between the heated wall and bulk fluid, which makes its use increasingly attractive in aerospace applications, such as compact evaporators in the thermal control of spacecraft environments, heat pipes, and the cooling of electronic equipment. The objective of the BCOEL project (Enhancement of Pool $\underline{\text { B }}$ oiling Heat Transfer and COntrol of Bubble Formation and Motion in Microgravity Using ELectric Fields) is to develop ways to overcome specific problems associated with boiling in the low gravity environment, in particular the inefficient bubble removal from the boiling surface, by substituting the buoyancy force with the electric field force. Previous studies indicate that in terrestrial applications, under certain conditions, boiling heat transfer rates can be increased by a factor of 50, when compared to values obtained for the same system without electric fields. Very little quantitative information is available on heat transfer rates in boiling in microgravity under the influence of electric fields.

The goal of the BCOEL project is to experimentally explore and model the physical mechanisms responsible for electrohydrodynamic (EHD) heat transfer enhancement in pool boiling in low gravity conditions and quantify the magnitude of enhancement for sets of operating conditions of interest in practical applications. This is accomplished by experimentally visualizing bubble 
shapes as well as temperature distributions in the vicinity of the heated surface and around the bubble during pool boiling using high-speed cinematography and real-time holographic interferometry (HI). Heat fluxes on the heated surface are also measured with conventional sensors. The experiments will be carried out on board of the International Space Station (ISS) within the framework of the Microgravity Science Glovebox (MSG) program.

It is expected that the results of the measurements will yield improved models of pool

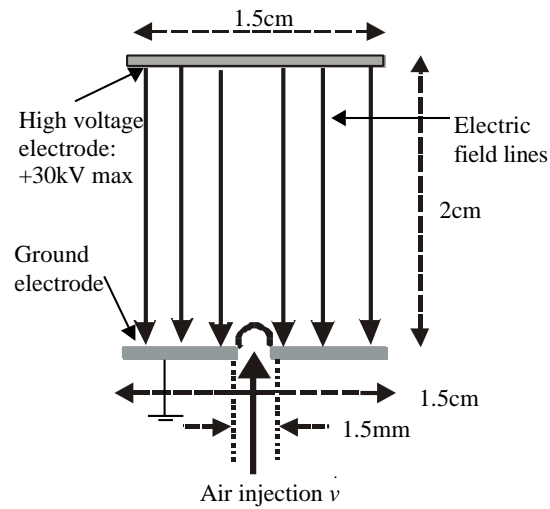

Figure 1. Schematic of the investigated physical situation

boiling under the influence of electric fields in the low gravity environment as well as under terrestrial conditions. A better understanding and the possibility to predict heat transfer rates in boiling under the influence of electric fields can lead to the development of heat transfer equipment for low gravity applications that relies on pool boiling, which opens new avenues for aerospace technology.

In the paper we first discuss the physical situation and the results of prior research concerning bubble formation in microgravity under the influence of electric fields. Bubbles were formed by the injection of air into the liquid in the test cell, PF5052. Next, we discuss the objectives of the ISS experiments and describe the concept of experimental hardware to be integrated into the MSG. Finally, we outline the experimental program.

\section{BUBBLE FORMATION IN MICROGRAVITY UNDER THE INFLUENCE OF ELECTRIC FIELDS}

During the project period 1996-2000, the influence of the electric field on a single bubble was investigated. Pool boiling was simulated by injecting a single air bubble into the liquid in the test cell, PF5052, through an orifice, as illustrated in Figure 1. In this approach, effects due to the presence of the electric field were separated from those caused by the temperature gradients in the thermal boundary layer. The approach of bubble injection (rather than boiling) was selected as it allows the experimenter to establish well-controlled experimental conditions (in particular the control of bubble formation rate and location). At the same time, many of the relevant properties, for example the relative magnitudes of the dielectric properties, relevant for the study of EHD effects, are retained. The influence of the thermal boundary layer was isolated by activating the resistive heater in the bottom electrode during a subset of experiments.

Two electrode shapes were investigated:
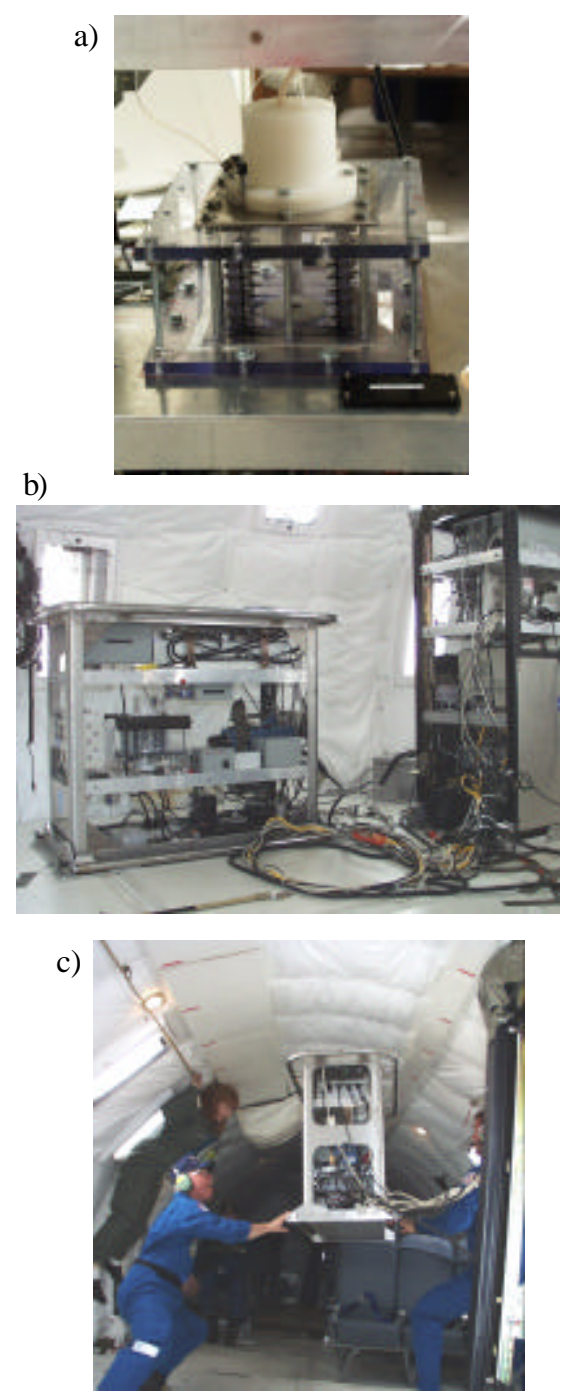

Figure 2. Photographs of the a) test cell, b) experimental rack mounted on the airplane structure and c) experimental rack in free-floating conditions in microgravity 
a) a parallel plate configuration generating an approximately uniform electric field and

b) a configuration with one plane (ground) and one spherical electrode (high voltage) that leads to the forming of a nonuniform electric field.
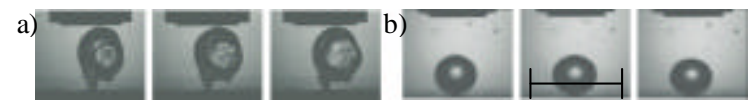

Figure 3. Typical bubble shapes in microgravity without electric field: a) Vertical coalescence and b) spherical bubble growth (Herman et al., 2001a).

Up to date, experiments with bubble injection through an orifice have been carried out under terrestrial conditions and in low gravity on board of the KC-135 (three flight series during the period 1999-2000). The test cell and the experimental setup used in these experiments are shown in Figure 2. More details regarding the experimental hardware and method are available in Herman et al. (2001a).

The bubble was exposed to a static d.c. electric field of magnitudes ranging between 0 and $25 \mathrm{kV}$, formed between the bottom electrode and a parallel top electrode, spaced $20 \mathrm{~mm}$ apart (Figure 1). The bottom electrode is a $15 \mathrm{~mm}$ diameter copper cylinder with a $1.5 \mathrm{~mm}$ diameter orifice in its center. It is electrically grounded. The copper cylinder can be heated from below with a custom manufactured resistive heater $(R=12 \Omega)$ pressed against its bottom surface. The heater is used in heat transfer experiments. The copper cylinder is equipped with 6 thermocouples that allow the monitoring of surface temperature. The copper cylindrical top electrode is electrically insulated (with a Polycarbonate cylinder) on all its surfaces except for the one parallel to the bottom electrode, which is exposed to the liquid in the test cell. The diameter of the top electrode is identical to the diameter of the bottom electrode. The high voltage cable, leading from the high voltage power supply located on the top shelf of the experimental rack, is threaded to the top electrode in the test cell. The ground electrode, the ground ports of all equipment in the experimental and computer

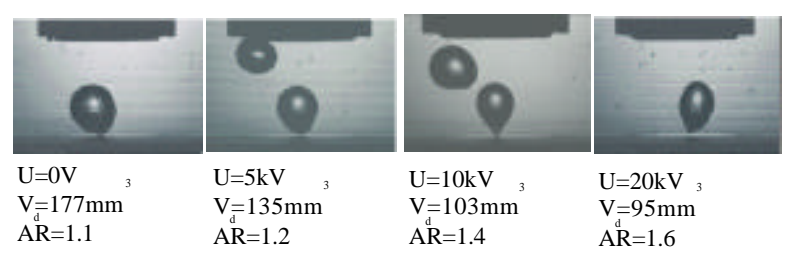

Figure 4. Bubbles at detachment in microgravity for electric potential differences of $U=0,5,10$ and 20kV (Herman et al., 2001a). racks and the rack frames are connected to a common point that is connected to the ground of the KC-135. The test cell can be drained through a port on the bottom of the test cell and the air injected into it during the experiments is removed through the pressure relief system.

A period of approximately $20-25$ s of low gravity, with acceleration levels between 0.001 and $0.02 \mathrm{~g}$, was available per parabola during the microgravity experiments in the KC-135. The experimental apparatus was either anchored to the aircraft structure or operated in free-floating conditions. In this latter case a better quality of low gravity was available (the g-jitter is reduced), however, the low-gravity periods were shorter (because of the eventual impact of the experimetal setup on the walls of the aircraft) and lasted only about 5s. In the present study experiments were carried out both in free-floating and bolted-down configurations.

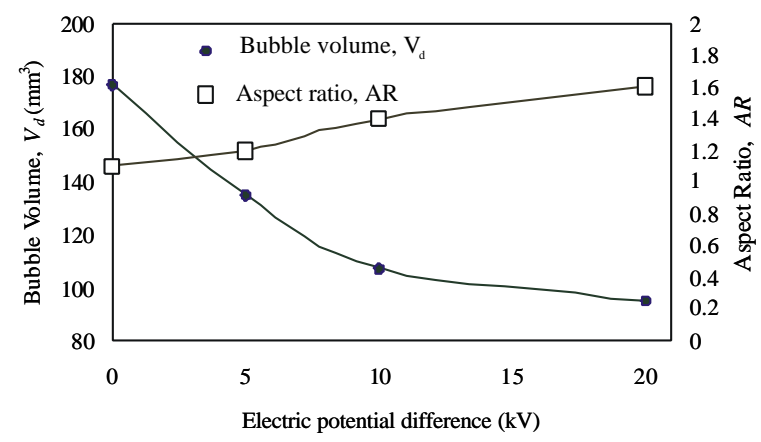

Figure 5. Bubble volume and aspect ratio at detachment for the bubbles shown in Figure 4 as function of the applied electric potential difference (Herman et al., 2001a).

Characteristic bubble sequences recorded in microgravity are displayed in Figure 3. They illustrate some of the typical behavior patterns of injected air bubbles without electric fields in microgravity. The gas-liquid interface instability on the surface of a large, nearly spherical bubble, at a stage of development close to detachment, is illustrated in Figure 3a. A similar corrugated surface structure has also been observed in microgravity boiling experiments. The bubble in Figure $3 \mathrm{a}$ has reached its detachment size but remains attached, connected to the orifice by a large neck that may also have been formed by the new gas bubble developing underneath the large bubble. In the absence of buoyancy and vertical acceleration the bubble rests motionless in the liquid. The overall shape of the bubble remains unchanged while the local interfacial instabilities 
rapidly deform the surface creating an effect resembling to surface waves.

Regular bubble growth in the absence of electric fields in microgravity is illustrated in Figure $3 \mathrm{~b}$. The presented sequence was recorded in freefloating conditions. The spherical bubble grows uniformly, and, after it has reached its detachment size, it exhibits periodic, small, vertical elongation and flattening. The lower portion of the bubble remains in contact with the bottom electrode and no neck is forming. The bubble eventually detaches only after the impact of the experimental rack against the wall of the aircraft.

The experimental realizations displayed in Figure 3 illustrate the diversity of bubble behaviors observed in microgravity in the absence of electric fields. One parameter that was found to allow predicting bubble behavior in microgravity in previous studies is the Weber number. According to the results of the 4.74s microgravity experiments of Pamperin and Rath (1995) carried out in a drop tower, bubble detachment does not occur for $\mathrm{We}<6$ and bubbles exhibit regular detachment behavior for $\mathrm{We}>10$. The volume flow rate regime considered in this study corresponds to Weber numbers from 3.3 to 8.8 , which is an intermediate regime, and the wide variety of bubble behaviors observed in our experimental study could be attributed to this condition.

Since bubble formation and behavior in microgravity is extremely sensitive to acceleration, the variations in bubble behavior could also be caused by small residual acceleration components. Therefore experiments in an environment with lower g-jitter (such as the ISS) are essential to understand the reasons for some of the behavior patterns observed in these experiments. The described behaviors were observed for different volume flow rates, and therefore a particular behavior pattern could not be uniquely associated with a particular flow rate. Bubble volumes at detachment (caused by the impact of the test cell on the walls of the aircraft, lateral acceleration components, onset of high gravity or by the regular detachment mechanism) varied in a wide range.

Shapes of injected air bubbles recorded at the moment of detachment for electric potential

differences of $U=0,5,10$ and $20 \mathrm{kV}$ are presented in Figure 4. Without the electric field, the bubble in Figure $4 \mathrm{a}$ is almost spherical (aspect ratio of 1.1) and its volume is $177 \pm 3 \mathrm{~mm}^{3}$. Based on Figures $4 b-d$ it can be concluded that the electric field has a considerable impact on bubble shape at detachment.
By increasing the electric potential difference between the two electrodes, bubble elongation in the direction parallel to the applied electric field becomes more pronounced.

From the measurement data it follows that the characteristic dimensions, the volume and the contact angle at detachment are also affected by the presence of the electric field. The aspect ratio $A R$, defined as the ratio of bubble height to width, increases with the electric potential difference, while the bubble volume decreases. The aspect ratio $A R$ and bubble volume at detachment $V_{d}$ as function of the applied electric potential difference $U$ are presented in the diagram in Figure 5. The aspect ratio increase is approximately linear, while the most pronounced decrease of the bubble volume was observed between 0 and $10 \mathrm{kV}$. Increasing the applied electric potential difference from 0 to $20 \mathrm{kV}$ causes an aspect ratio increase of $45 \%$ and the detachment volume decrease of $46 \%$. Due to the elongation of the bubble, the contact angle increases from $47^{\circ}$ to $60^{\circ}$, corresponding to a $28 \%$ change.

Regular bubble detachment is observed in microgravity under the influence of electric fields, contrasted to irregular bubble shape, behavior and detachment for the same case without electric fields. After detachment, bubbles move away from the surface at which they form. Bubble coalescence was found to be less pronounced in microgravity in the presence of electric fields. The influence of electric fields on gas-liquid systems is more pronounced in microgravity than in terrestrial conditions. More details regarding the experimental results are available in Herman et al. (2001a).

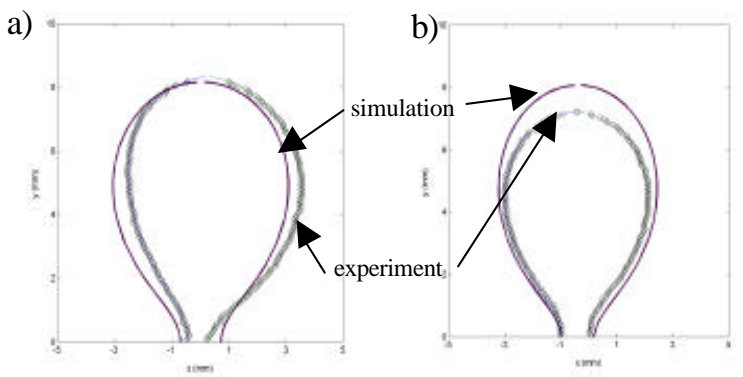

Figure 6. Comparison of experimental and computed bubble contours for a) no electric field and b) an electric potential difference of $20 \mathrm{kV}$ (Herman et al. 2001b).

One can notice that even with the highest electric potential difference $(20 \mathrm{kV})$ applied, the average bubble volume at detachment in microgravity $\left(91 \mathrm{~mm}^{3}\right)$ is an order of magnitude higher than the bubble volume in terrestrial gravity $\left(9.5 \mathrm{~mm}^{3}\right)$. 
Therefore it can be concluded that in the investigated configuration (static and uniform electric field up to $E=10 \mathrm{kV} / \mathrm{cm}$ ) the electric field forces are not strong enough to completely substitute for the buoyancy forces typical of terrestrial conditions. In addition to increasing the electric field magnitude to accomplish this goal, experiments with electrode configurations leading to a non-uniform electric field, that could potentially enhance the influence of the electric field, are planned in the future.

Apart from the experimental studies, existing simplified analytical models describing bubble formation at an orifice and during boiling were evaluated (Fritz, 1935; Cheng and Chaddock 1986; Kumar and Kuloor, 1970) and modified to accommodate the physical effects considered in the NASA study. Measured bubble shapes were compared with predictions obtained using simplified analytical models, and representative results are shown in Figure 6 (Herman et al., 2001b). The experimental data show good agreement with model predictions. More details regarding the modeling efforts are available in Herman et al. (2001b).

During the project period 2000-2001 the investigation of bubble coalescence and boiling at predefined nucleation sites has commenced. Boiling is being visualized and bubble form and temperature distributions with and without electric fields will be compared using data generated in terrestrial conditions and microgravity. A subset of these experiments will focus on the interaction of bubbles (again using bubble injection) to evaluate the affinity of bubbles for merging, which was shown to have a considerable impact on heat transfer in microgravity.

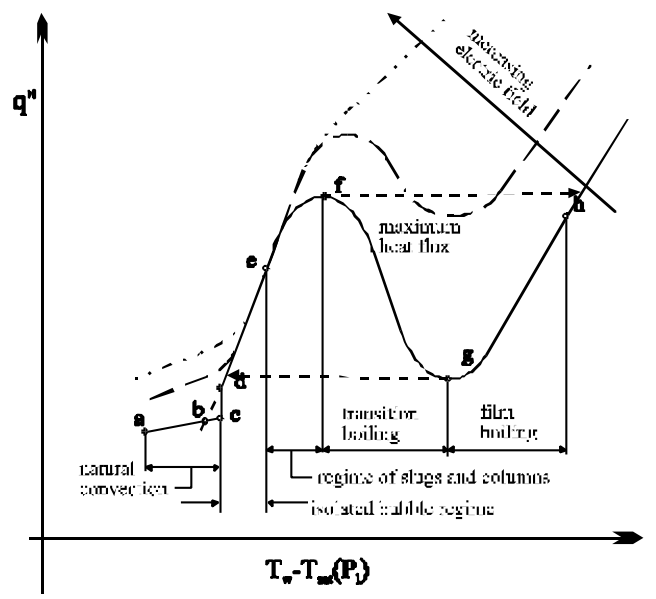

Figure 7. Pool boiling curve and changes due to the influence of the electric field according to Grassi and DiMarco (1992).

\section{GLOVEBOX EXPERIMENT}

The Glovebox experiment in the present study focuses on the investigation of the influence of electric fields on boiling in the low gravity environment at different points along the boiling curve (shown in Figure 7 for the prescribed surface temperature boundary condition for which temperature is varied as independent variable). Experiments will be conducted for the controlled surface heat flux boundary condition. One of the objectives of the research will be the identification of boiling regimes along the boiling curve in microgravity under the influence of electric fields.

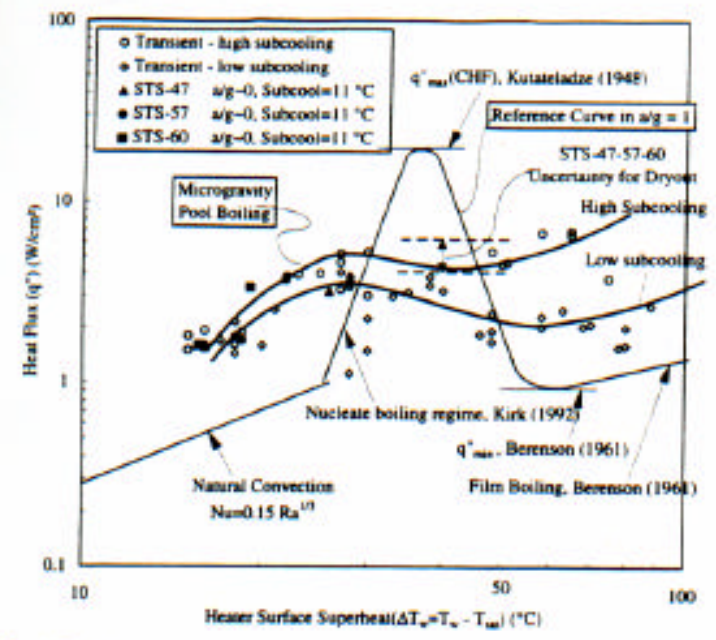

Figure 8. Pool boiling curve in microgravity conditions compared to that in terrestrial conditions according to Merte at al. (1996)

\section{Background on the boiling curve}

A large amount of theoretical and experimental research has been done on EHD enhanced pool boiling in terrestrial conditions, that has potential applications in cryogenic engineering, heat exchangers and heat transfer enhancement in general. The presence of bubbles significantly increases the complexity of EHD phenomena, and causes dramatic changes of the boiling cycle, as illustrated in Figure 7.

Grassi and DiMarco (1992) reviewed the effects of gravity and electric fields on pool boiling. They showed that the improved heat transfer performance is commonly related to the change in the boiling curve, as illustrated in Figure 7 by the dashed lines. As a result of the superposition of the electric field, the natural convection and peak heat fluxes are increased, transition boiling can be suppressed, resulting in a more monotonous increase of the boiling curve. These authors emphasize that tests of EHD enhanced pool boiling in reduced gravity can 
also improve the comprehension of the basic underlying physics of boiling.

Microgravity pool boiling curves for R113 were recorded by Merte and coworkers. Pool boiling curves, one for a higher level of subcooling and another one for a lower level of subcooling (Merte, 1996), are contrasted to a boiling curve for terrestrial conditions in Figure 8. The curves appear much flatter in microgravity than in terrestrial gravity. The critical heat flux was found to decrease significantly in microgravity. The results indicate that increased subcooling was associated with an increase in heat transfer.

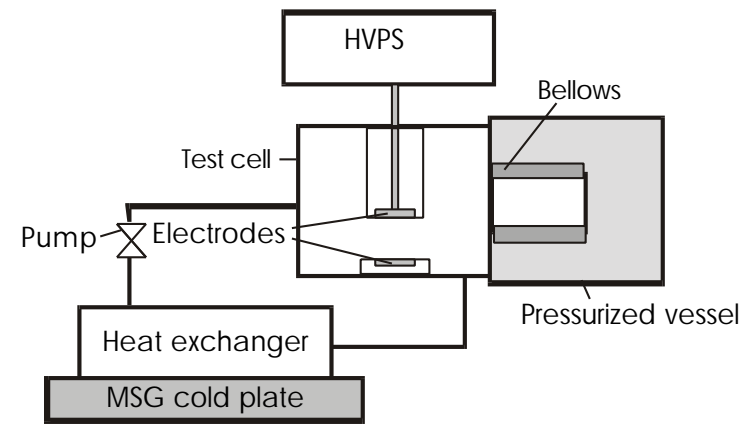

Figure 9. Schematic of the experimental setup

Several basic mechanisms involved in the boiling process, such as bubble growth on the wall and detachment, electric charging of bubbles, bubble buoyancy and rise velocity as well as the liquid vapor interface stability are expected to be influenced by the presence of electric fields. The process of EHD enhanced boiling in terrestrial conditions was analyzed experimentally using high-speed cinematography as well as numerically. The videotapes of bubble formation and motion to be recorded during the experiments of the BCOEL project will help interpret the data and provide better insight into the physics of the process.

\section{Objectives of the BCOEL MSG \\ experiment}

The objective of the BCOEL MSG experiment is to generate boiling curves similar to those in Figures 7 and 8 for microgravity under the influence of electric fields. These experiments will be carried out by imposing different heat fluxes $q^{\prime \prime}$ to the surface of the copper block. To generate boiling curves such as those shown in Figures 7 and 8, the surface temperature of the copper block $T_{w}$ is measured. Boiling regimes along the boiling curve in microgravity under the influence of electric fields will be identified. Boiling takes place on a heated copper surface that serves as the ground electrode. Boiling curves are typically generated for different pressures and different levels of subcooling.

\section{Experimental setup}

The schematic of the experimental setup for the MSG experiments is presented in Figure 9. The hardware is a combination of the test cell with bellows used in Merte's PBE and a flow loop with a pump and heat exchanger. The heat exchanger will be attached to the cold plate of the Glovebox hardware. The flow loop allows to quickly bring the working fluid to the

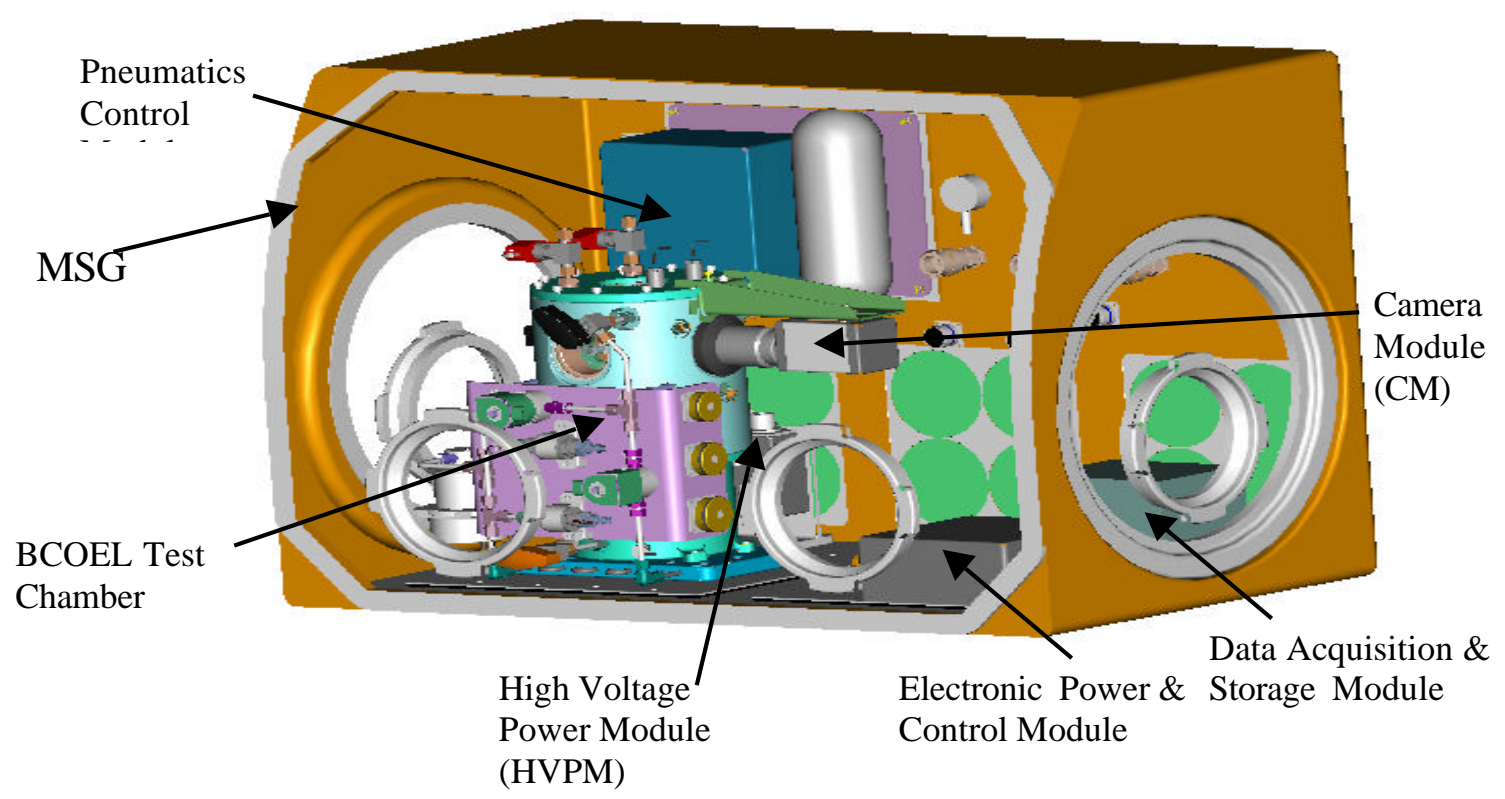

Figure 10. BCOEL hardware installed in the MSG 


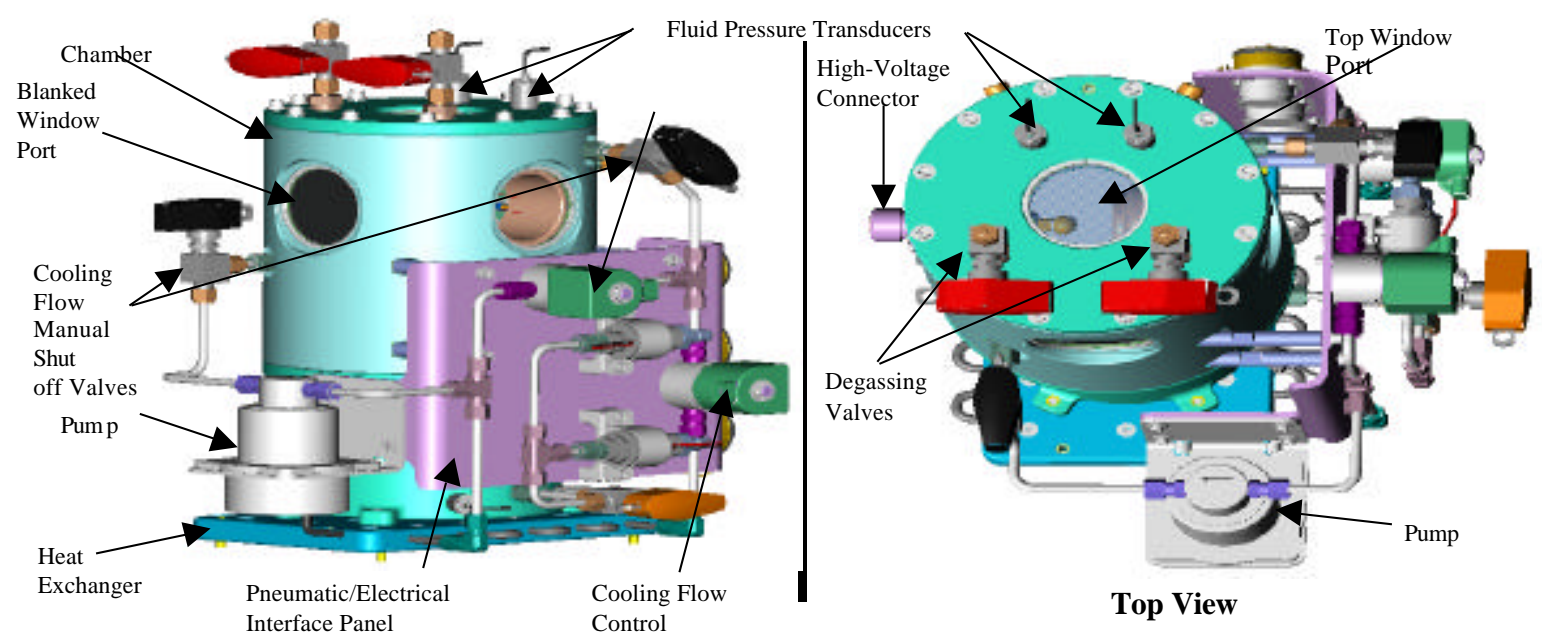

Figure 11. BCOEL test chamber assembly: side view (left) and top view (right)

desired temperature (specified by the level of subcooling for the next experimental run) after each experiment. The BCOEL hardware installed in the MSG is shown in Figure 10 and the mechanical assembly with the individual components of the setup in Figure 11. The test cell material is Aluminum, and its volume is approximately 2 liters. The diameter of the measurement volume is $\sim 150 \mathrm{~mm}$ and its height $\sim 120 \mathrm{~mm}$. The degassing of the working fluid will be accomplished in the test cell.

\section{Working fluid}

FC-72 (http://www.3m.com/market/industrial/fluids) has been selected as the working fluid in the experimental study. Its boiling point is $56^{\circ} \mathrm{C}$ at

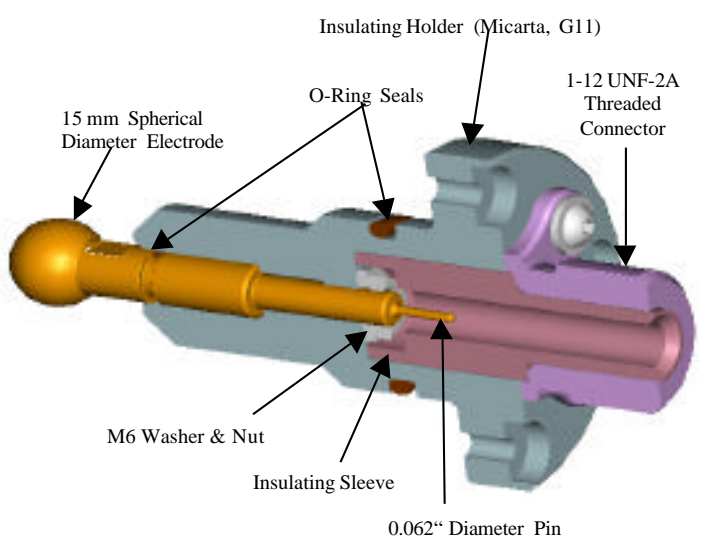

Figure 12.30kV electrode assembly

atmospheric pressure, the fluid is electrically insulating, nontoxic and environmentally safe. The working fluid in the test cell is degassed prior to the experiments. The degassing takes place in the test cell prior to the flight.

\section{Experimental parameters}

\section{Potential difference between electrodes}

The potential difference between the ground electrode and the high voltage electrode will be varied in the range of $0-20 \mathrm{kV}(0,+10,+15,+20)$. The reference situation is the one with $0 \mathrm{~V}$ potential difference between the electrodes. A separate boiling curve will be measured for each potential difference (for a variation of the heat flux $q^{\prime \prime}$ in the full range). The maximum potential difference (electric field magnitude) should be as high as possible, determined by safety considerations (to avoid the forming of a spark between the electrodes). The voltage applied between the high-voltage and the ground electrode will be monitored during the experimental run. The high voltage power supply will be equipped with a bleed-out resistor (that allows the discharging of the electrodes after the device has been shut down) as well as short circuit protection. The design of the electrode assembly is displayed in Figure 12.

Heat flux $q^{\prime \prime}$ applied to the resistive heater in the bottom (ground) electrode

The experiments will be carried out by varying the heat flux $q^{\prime \prime}\left(q_{1}^{\prime \prime}, q_{2}^{\prime \prime}, q_{3}, q_{4}^{\prime \prime}\right)$ delivered by the resistive heater (by increasing the current passing through the resistor) and measuring the corresponding surface temperature $T_{w} . T_{w}$ is monitored with several temperature sensors. The surface temperature in boiling curves is commonly expressed in terms of $T_{w}-T_{s a t}(p) . T_{s a t}(p)$ is the saturation temperature 
of the fluid at a pressure $p$. The heated surface, the ground electrode, is a $15 \mathrm{~mm}$ diameter copper cylinder. The resistive heater and the thermocouples are electrically insulated from the copper electrode. The structure of the heater insert assembly is displayed in Figure 13. The magnitude of the heat fluxes, step sizes, the duration of the steps and the total range of heat fluxes for experimental runs on board of the ISS will be determined in KC-135 experiments, since information available in the literature is insufficient to accurately predict the heat flux - temperature dependence.

The electrical power supplied to the resistive heater and converted into heat will be delivered partly to the working fluid through the copper ground electrode and partly to the insulation backing beneath the resistive heater. The heat flux supplied to the working fluid is determined based on the signals read by the temperature sensors in the copper block. The resistive heater is capable of delivering 50W max, and it is shut down as soon as the temperature of the heated surface exceeds the value prescribed by safety considerations.

\section{Level of subcooling}

The level of subcooling is the temperature difference between the bulk liquid temperature and the saturation temperature. The temperature of the bulk liquid is constant throughout the volume of the test cell prior to an experimental run (with $0.2{ }^{\circ} \mathrm{C}$ accuracy). The bulk fluid temperature is monitored throughout the experiment with a series of strategically positioned temperature sensors. Boiling curves will be generated for different levels of subcooling at atmospheric pressure. The nominal temperature of the fluid is $56^{\circ} \mathrm{C}$ (corresponding to $\mathrm{T}_{\text {sat }}$ at $14.7 \mathrm{psia}$ ). Three levels of subcooling $\left(5,15,25^{\circ} \mathrm{C} \pm 2{ }^{\circ} \mathrm{C}\right)$ will be investigated in the BCOEL microgravity study.

\section{Pressure}

Boiling curves are typically generated for different fluid pressures. In the ISS experiment the fluid pressure will be maintained at atmospheric pressure, at $1.013 \times 10^{5} \mathrm{~N} / \mathrm{m}^{2}$ (14.7 psia) prior to and after initial nucleation of boiling. The pressure in the test cell should remain constant throughout the experiment and it is monitored. Since the pressure in the test cell can increase during an experimental run due to boiling, pressure compensation is necessary. It will be accomplished by means of bellows, as shown in Figure 9. A short-duration pressure spike is expected to occur at the immediate onset of boiling, before the pressure control provided by the bellows can respond. The presence of the pressure spike will

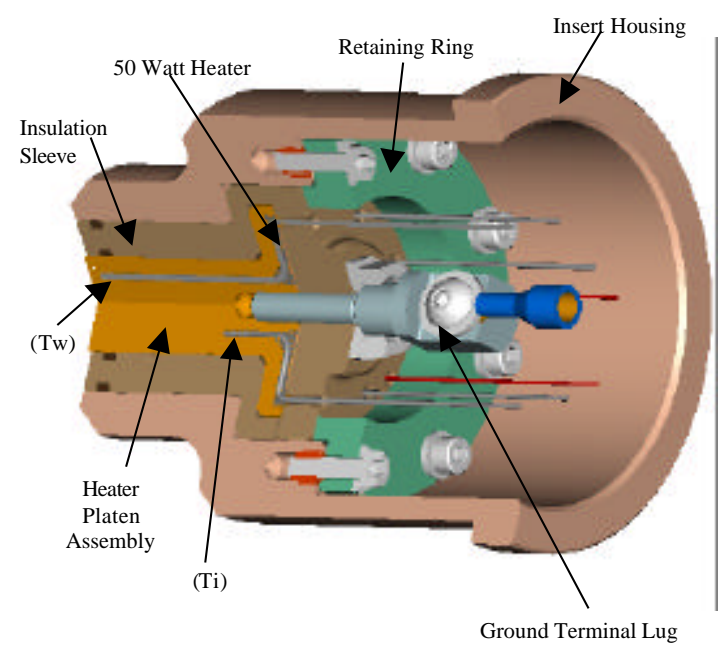

Figure 13. Heater insert assembly

be accounted for in the interpretation of the experimental data.

\section{Monitoring of experimental variables}

Fluid temperature, wall temperature of the heated electrode, system pressure, applied potential difference and acceleration levels are monitored throughout the experiments. Data will be recorded by the data acquisition system. Pool boiling is sensitive to acceleration and g-jitter. Acceleration is monitored by a triaxial acceleration sensor mounted in the vicinity of the test cell. Acceleration data will be matched with individual images recorded by the highspeed video camera. Acceleration levels less than $10^{-3} \mathrm{~g}$ are desired during the experimental runs, but they are not actively controlled. Experiments will be run during quiescent periods when there are no crew exercise or any other major disturbances.

A high-speed video camera will be used to visualize bubble formation during boiling. Because of the high bubble formation rates during boiling, recording rates of 500 frames/sec. and spatial resolutions of $512 \times 512$ pixels are desired. Visualization images recorded by the high-speed camera will be synchronized with data recorded by the data acquisition system.

\section{CONCLUSIONS}

It is expected that the results of the measurements will yield improved models of pool boiling under the influence of electric fields in the low gravity environment as well as in terrestrial conditions. A better understanding and the possibility to predict heat transfer rates in boiling under the influence of 
electric fields can lead to the development of heat transfer equipment for low gravity applications that relies on pool boiling, which opens new avenues for aerospace technology. The experiments on board of the ISS are tentatively scheduled during the year 2004.

\section{REFERENCES}

1. Cheng, K.J. \& Chaddock, J.B. (1984). Deformation and stability of drops and bubbles in an electric field. Physics Letters, 106A, 51-53.

2. Cheng, K.J. \& Chaddock, J.B. (1986). Maximum size of bubbles during nucleate boiling in an electric field. International Journal of Heat and Fluid Flow, 7, 278-282.

3. Fritz, W. (1935). Berechnung des Maximalvolumens von Dampfblasen. Physikalishe Zeitschrift, 36, 379-384.

4. Grassi, W. \& Di Marco, P. (1992). Gravity and electric field effects on pool boiling heat transfer. Proceeding of the VIIIth European Symposium on Materials and Fluid Sciences in Microgravity, Brussels ESA SP-333:783-788.

5. Herman, C., Iacona, E., Foldes, I.B., Suner, G. \& Milburn, C. (2001a). Experimental visualization of bubble formation from an orifice in microgravity in the presence of electric fields, accepted for publication in Experiments in Fluids, in print.
6. Herman, C., Földes, I.B., Iacona, E. \& Milburn, C. (2001b). Bubble detachment in microgravity under the influence of electric fields: Modeling and experiments. Submitted to Chem. Eng. Sci., in review.

7. Kumar, R. \& Kuloor, N.R. (1967a). Blasenbildung in Flüssigkeiten niedriger Viskosität (mit Oberflächenspannung) unter konstanten Strömungsbedingungen. Chemische Technik, 19(2), 78-82.

8. Kumar, R. \& Kuloor, N.R. (1970). The formation of bubbles and drops. Advances in Chemical Engineering, Eds. T.B. Drew, G.R. Cahelet, J.W. Hopes, T. Vermeulen, Am. Chem. Soc. Washington, 8, 256-368.

9. Merte, H. Jr., Lee, H.S. \& Keller R.B. (1996). Report on Pool Boiling Experiment Flown on STS-47 (PBE-IA), STS-57 (PBE-IB) and STS-60 (PBE-IC), NASA Contactor Report 198465 UMMEAM-95-01, Prepared for NASA Lewis Research Center.

10. Pamperin, O. \& Rath, H.J. (1995). Influence of buoyancy on bubble formation at submerged orifices. Chem. Eng. Sci. 50:3009-3024.

11. Yabe, A., Mori, Y. \& Hijikata, K. (1995). Active heat transfer enhancement by utilizing electric fields. Annual Review of Heat Transfer, Ed. Chang-Lin Tien, Vol. 7, chap. 4. Begell House, New York. 
Public reporting burden for this collection of information is estimated to average 1 hour per response, including the time for reviewing instructions, searching existing data sources, gathering and maintaining the data needed, and completing and reviewing the collection of information. Send comments regarding this burden estimate or any other aspect of this collection of information, including suggestions for reducing this burden, to Washington Headquarters Services, Directorate for Information Operations and Reports, 1215 Jefferson Davis Highway, Suite 1204, Arlington, VA 22202-4302, and to the Office of Management and Budget, Paperwork Reduction Project (0704-0188), Washington, DC 20503.

\begin{tabular}{|l|l|l|}
\hline 1. AGENCY USE ONLY (Leave blank) & $\begin{array}{c}\text { 2. REPORT DATE } \\
\text { December } 2001\end{array}$ & $\begin{array}{r}\text { 3. REPORT TYPE AND DATES COVERED } \\
\text { Technical Memorandum }\end{array}$ \\
\hline
\end{tabular}

\section{TITLE AND SUBTITLE}

5. FUNDING NUMBERS

Enhancement of Pool Boiling Heat Transfer and Control of Bubble

Motion in Microgravity Using Electric Fields (BCOEL)

\section{AUTHOR(S)}

Cila Herman, Estelle Iacona, Tom Acquaviva, Bill Coho, Nechelle Grant,

Henry Nahra, Al Taylor, Ed Julian, Dale Robinson, and Dave VanZandt

\section{PERFORMING ORGANIZATION NAME(S) AND ADDRESS(ES)}

National Aeronautics and Space Administration

John H. Glenn Research Center at Lewis Field

Cleveland, Ohio 44135-3191

WU-101-43-0B-00

\section{SPONSORING/MONITORING AGENCY NAME(S) AND ADDRESS(ES)}

National Aeronautics and Space Administration

Washington, DC 20546-0001

8. PERFORMING ORGANIZATION REPORT NUMBER

E-13116

\section{SUPPLEMENTARY NOTES}

Prepared for the International Space Station Utilization-2001 sponsored by the American Institute of Aeronautics and Astronautics, Cape Canaveral, Florida, October 15-18, 2001. Cila Herman and Estelle Iacona, Johns Hopkins University, Department of Mechanical Engineering, 3400 N. Charles Street, Baltimore, Maryland 21218 (work funded by NASA Grant NAG3-1815); Tom Acquaviva, Bill Coho, Nechelle Grant, Henry Nahra, and Al Taylor, NASA Glenn Research Center; Ed Julian, Dale Robinson, and Dave VanZandt, ZIN Technologies, Inc., 3000 Aerospace Parkway, Brook Park, Ohio 44142. Responsible person, Henry Nahra, organization code 6712, 216-433-5385.

Unclassified - Unlimited

Subject Categories: 34 and 37

Distribution: Nonstandard

Available electronically at http://gltrs.grc.nasa.gov/GLTRS

This publication is available from the NASA Center for AeroSpace Information, 301-621-0390.

\section{ABSTRACT (Maximum 200 words)}

The BCOEL project focuses on improving pool boiling heat transfer and bubble control in microgravity by exposing the fluid to electric fields. The electric fields induce a body force that can replace gravity in the low gravity environment, and enhance bubble removal from the heated surface. A better understanding of microgravity effects on boiling with and without electric fields is critical to the proper design of the phase-change-heat-removal equipment for use in spacebased applications. The microgravity experiments will focus on the visualization of bubble formation and shape during boiling. Heat fluxes on the boiling surface will be measured, and, together with the measured driving temperature differences, used to plot boiling curves for different electric field magnitudes. Bubble formation and boiling processes were found to be extremely sensitive to g-jitter. The duration of the experimental run is critical in order to achieve steady state in microgravity experiments. The International Space Station provides conditions suitable for such experiments. The experimental apparatus to be used in the study is described in the paper. The apparatus will be tested in the $\mathrm{KC}-135$ first, and microgravity experiments will be conducted on board of the International Space Station using the Microgravity Science Glovebox as the experimental platform.

\section{SUBJECT TERMS} 15. NUMBER OF PAGES

Boiling; Heat flux; Superheat; Subcooling; Electric field 15

\begin{tabular}{|c|c|c|}
\hline $\begin{array}{c}\text { 17. SECURITY CLASSIFICATION } \\
\text { OF REPORT } \\
\text { Unclassified }\end{array}$ & $\begin{array}{c}\text { 18. SECURITY CLASSIFICATION } \\
\text { OF THIS PAGE } \\
\text { Unclassified }\end{array}$ & $\begin{array}{c}\text { 19. SECURITY CLASSIFICATION } \\
\text { OF ABSTRACT } \\
\text { Unclassified }\end{array}$ \\
\hline
\end{tabular}

